\title{
Formation and development of digital transformation of domestic education on the basis of systemic convergence of pedagogical science and technology
}

\author{
Irena Veniaminovna Robert*
}

State Budget Scientific Institution Institute for Strategy of Education Development of the Russian Academy of Education

\begin{abstract}
This paper justifies and defines the terms "digital transformation of education" and "digital paradigm of education". It reveals the essence of the system approach in the formation of the digital paradigm of education, and presents the conditions needed to form the values of domestic education in the digital paradigm period. The work also shows how to form a digital paradigm of domestic education based on a systematic convergence of pedagogical science and technology.
\end{abstract}

\section{Introduction}

The modern student perceives the world of the XXI century in the context of formalizing the results of his/her activities (in the form of indicators, charts, infograms, graphs, matrices, various visualizations, etc.), including formalization of his/herself as a person in the virtual world (selfies in the form of digital photos or videos, portfolios, profile pics, resumes, etc.). Network communication when communicating with other people is essential to the formalization of the individual as a unique personality, and in this process, young people, seek self-expression and self-actualization, sometimes pursuing anything but good causes. Currently used MS Teams, Webinar.ru, YouTube, Zoom, Mirapolis, Skype for collective communication also initiate formalization, both in the construction of dialogue, and formation of conditions for information interaction. Professional activity of a modern person also requires formalization and standardization, in the form of indicators (e.g., in science, in education) or ratings (e.g., in culture).

In addition, active use of technologies to reflect the reality in the virtual space with contactless information impact on its objects and processes (virtual, augmented, mixed, augmented reality) gives rise to a sense of "policy of all-permissiveness" in the virtual world. At the same time, normal natural fears experienced by an individual in real life when interacting with other people (possibility of being rejected by society, possibility of not being understood by the other person, possibility of being alone) are weakened or even disappear during informational interaction in social networks, in various chat rooms, especially in the context of anonymous representation of oneself as a person in the virtual world.

\footnotetext{
${ }^{*}$ Corresponding author: rena_robert@mail.ru
} 
These processes, unfortunately, do not contribute to the development of an individual's creativity, genetically inherent by nature, which dictates the need for a more detailed consideration of significant effects (positive, negative) on the student due to their active and systematic use of modern information and communication technologies (ICTs), both digital and analogue form of implementation, in the educational, professional, recreational activities [7]; [8]; [12].

Thus, the positive impact of the process of using ICTs on the student includes:

- intellectualization of learning and cognitive activity of student through the use of virtual tools to create the studied objects and processes or to study abstract models and concepts on the screen (a tool for simulation of the studied objects, processes, both real and virtual; a tool for simulation of real objects or processes on the screen; a tool for design of the screen interface) in accordance with the pedagogical feasibility;

- expansion of student's understanding of the content of learning material through a virtual representation of the same object or process from different points of view of different subject areas or from different conceptual approaches (philosophical, sociological, scientific, etc.), or from a variety of versions of the studied process, phenomenon, plot (both real and virtual);

- increase of motivation for education through: automation of search, processing, formalization, production, replication of training information; management of virtual models of studied objects, processes; user participation in the processes of virtual reality with the ability to influence them; hypertext and hypermedia forms of presentation of learning material, allowing to expand both the topic and the spectrum of its presentation, facilitating search, interpretation and choice of the desired aspect of the content;

- promotion of student's activity through: implementation of information activity, information interaction between the subjects of the educational process with an interactive information resource; implementation of teaching methods that correspond to modern research methods of knowledge of the studied patterns of natural phenomena and social manifestations, both real flowing and virtual.

Possible negative consequences of the impact of ICT use on the student includes:

- weakening of student's discursive (reasoning) type of thinking and the prevalence of divergent and algorithmic styles of thinking, manifested in weakening of the ability to concentrate on isolating the essential features of selected information, due to the fact that when searching for information in any search engine (Yandex, Google, Apple, etc.) the user is likely to remember not the content of information, but the search algorithm;

- difficulties in the student's understanding of the target, structural and content-related, moral and value component of information when perceiving and using it, due to the priority of visual representation of information over content, which reduces the level of student's understanding of the content of information, but increases visual perception of information presented in compressed form (pictograms, charts, diagrams, graphs, infographics, etc.);

- inability to isolate the content component of educational information due to a preference for visualization, simulation - a factual description of the considered or studied object, process or story, leading to a superficial perception of educational information by the student;

- student's orientation to precisely follow the pre-learned algorithms of class activities within the framework of outdated ideas of behaviorism (any action causes a backlash, a response) due to orientation of the education process on finding several solutions to a single problem. 


\section{Digital transformation of education as the basis for the formation and development of digital education paradigm}

The aforementioned changes occurring in education (positive and negative), were a systemforming factor for the emergence of digital transformation of education, by which we will understand the aggregate of significant changes occurring in education (positive and negative), as a result of the implementation of digital technologies with their active and systematic use in educational purposes. Many processes in education underwent digital transformation: provision of educational services; creation of digital educational resources; information and methodological support of educational process; information activities; information interaction, both between the subjects of the educational process, and with digital educational resources; management of educational process; information provision and organizational management of education provider; personal information security of the subjects of the educational process. Currently, the impact of digital transformation extends to the entire sphere of education in the following directions: teaching and educational process, processes of creating and using electronic or digital educational resources, formation of the structure of information and educational environment using high-tech and mobile equipment, providing remote access to educational content, tools and systems for automation of administration and management of education provider, etc. The very process of digital transformation of education initiates improvement of the entire education system, in particular: updating and modifying all educational and methodological materials, including content and structure of various educational programs, competencies, tools for assessment of student's achievements and management of educational process; organizing and equipping scientific, experimental activities for students; structuring and organizing training and retraining of teaching and managerial staff to use digital technology in solving professional problems; developing information infrastructure of education provider. [7]; [8]; [11].

On the modern pedagogical and technological level, positive effect of the aforementioned processes is possible only with the creation of methodological, scientific and pedagogical provisions and technological solutions, focused on socialization and intellectual development of the individual on the basis of implementation of modern scientific and technological progress of this period of active use of digital technology while preventing possible negative effects on the health of students and personal information security of the subjects of the educational process. The aggregate of the aforementioned approaches we will call the digital education paradigm, the formation and development of which involves the creation of a system of scientific views on theoretical, methodological, technological developments and solutions for the implementation of digital technology opportunities for the development of education in all its aspects (training, education, awareness, development) ensuring health protection and personal information security of the subjects of the educational process. [7]; [8]; [11].

\section{The essence of systemic approach in the formation of digital education paradigm}

It is well known that any system is a set of a particular variety of elements or components (objects, subjects), which have certain relations and connections with each other, forming certain integrity, unity. In this connection, involvement of systemic approach to formation and development of a digital education paradigm is conditioned by the fact that the creation of a set of theoretical, methodological, technological developments and solutions aimed at the formation of a digital education paradigm correlates, first, with the presence of a certain variety of elements (or components), which includes following results of fundamental and applied scientific research in the field of education informatization: 
- convergent teaching methods, representing a logically complete block of information reflecting content-related and methodological basis for studying the subject area(s) using ICTs in the context of convergence of ICT methods and methods of educational technology;

- values of education of digital paradigm period (philosophical and psychological, cognitive and intellectual, social (moral and ethical, cultural and aesthetic, convergent, national and ethnic, health protection, information security) [5];

- methods for evaluating the pedagogical and ergonomic quality of ICT-based pedagogical products [9];

- health protection approaches to the use of ICT in education [1]; [10];

- conditions ensuring personal information security of the subjects of educational process when using ICTs in the educational process [2]; [4].

Secondly, it correlates with the fact that the aforementioned components are in certain relationships and interrelations with each other, forming certain integrity, unity.

Let us explain this thesis in more detail, for which we will briefly describe the results of basic and applied scientific research in the field of informatization of education, dedicated to theoretical, methodological and technological developments as the basis for the formation of a digital education paradigm [1]; [2]; [4]; [5]; [6]; [7]; [8]; [9]; [10]; [11]; [12]. These include the following:

- content-related aspects of the development of digital transformation of education based on a systematic convergence of pedagogical science and ICT as a result of significant changes that have happened and ongoing in education (positive, negative), in connection with the use of digital technologies in the educational process;

- strategic benchmarks for the development of education (philosophical and methodological, psychological and pedagogical, technological, humanitarian and applied) in terms of digital transformation, in the context of the implementation of values of domestic education;

- development of training and education methodology in the context of digital transformation of education (organizational forms, methods and means of education, corresponding to the achievements of scientific and technological progress of modern society, while ensuring personal information security and protecting the health of the subjects of educational process);

- design of methodological systems of training and education, pedagogical technologies, focused on the development of student's personality in the context of digital transformation of education, as well as the formation of skills to independently acquire knowledge, carry out information activities and information interaction for educational purpose;

- organizational and methodological measures for prevention of possible negative consequences of psychological, pedagogical, social, cultural and medical nature when using information and communication technologies (ICTs for educational purposes);

- humanization of professional training in the context of digital transformation of education, formation of a professional worldview in the information-oriented society, use of information systems of diagnostics of the quality of educational systems;

- conditions of designing educational technologies, relevant from the pedagogical point of view, based on the implementation of possibilities of contactless information interaction technologies, as well as didactic and methodological support of their use in the educational process;

- requirements, relevant from the pedagogical point of view, for the creation and use of ICT-based pedagogical products (electronic (digital) educational resource; educational information systems; software and hardware and information complexes for virtual laboratory work; peripheral equipment interfaced with a computer; software and information support for the use of contactless information interaction technologies, etc.) ensuring 
personal information security and protecting the health of the subjects of the educational process;

- learning theories of period of digital transformation of education (theory of convergence of pedagogical science and ICT; theory of transfer-integrative areas of scientific and pedagogical knowledge; theory of information and educational space; theory of health protection when using ICT; theory of personal information security of the subjects of the educational process, theory of immersive educational technology design, etc.);

- theories of the educational process (sociocultural dependence of education in the context of digital transformation of education; patterns, principles of education of a young person at different stages of digital transformation of social relations; value foundations building the process of education in the context of development of digital technologies; pedagogical systems of education in the context of digital transformation of education).

Of the variety of results of basic and applied scientific research briefly described above, we will highlight the most significant ones.

Convergent methods of education at the present stage implement the possibilities of technologies to reflect the reality in the virtual space with contactless information impact on its objects or processes (virtual, augmented, mixed, extended reality). Let us focus on the description of their capabilities in the area of education.

"Virtual Reality" (VR) technology offers the user a set of methods, techniques and tools, the implementation of which provides: simulation of artificial reality (or virtual reality) on the screen, more or less adequate simulation of appearance and properties of real objects or processes, as well as any abstractions appropriate from the point of view of developers of educational products; contactless information interaction of the user, both with screen objects (remote, sensory, tactile implementation), and with other users; use of information presented in a wide range (stereo, audio, video, photographic, text, symbolic).

"Augmented Reality" technology (AR) offers the user a set of methods, techniques, methods and tools, the implementation of which provides: combining the reality and simulated virtual reality, represented by digital content, in the context of simultaneous presentation both real and virtual objects, processes, stories to the user; "overlaying" the digital content on the reality, representing it as real objects (eg, a book, furniture, etc.) and digital (electronic) format (eg, electronic educational resource, digital video, photo, etc.).

"Mixed Reality" (MR) or "Hybrid Reality" technology offers the user a set of methods, techniques, methods and tools, the implementation of which provides: combining real and virtual worlds to create digital visualizations in which the reality or real world objects (physical) and virtual reality objects (digital) coexist and interact with each other in real time; virtual objects acting according to the laws of real world and the virtual objects impacting the virtual world; mixing virtual reality and reality in interaction of real and virtual objects in real time with the ability to transform and modify the latter.

"Extended reality" technology (ER) offers the user a set of methods, techniques, methods and tools, the implementation of which provides: combining the virtual reality, augmented reality, mixed reality technologies; operation of programs that combine the elements of virtual reality, augmented reality, mixed reality technologies. [13]; [14]; [15]; [16]; [17]; [18]; [19]; [20]; [21]; [22]; [23]; [24]; [25]; [26]; [27]; [28]; [29]; [30].

In the analysis of convergent methods of ICT application, in particular in the context of using the aforementioned technologies, it should be noted that their development and use for educational purposes are directly related to methods for assessment of pedagogical and ergonomic quality of ICT-based pedagogical products [1]; [9]; [11], which include the following requirements:

- psychological and pedagogical requirements determine: compliance with age characteristics of students, implementation of the variability of education, use of 
developmental components in education, availability of ways to promote cognitive activity, availability of ways to form the experience of independent acquisition of knowledge, skills;

- content-related and methodological requirements determine: pedagogical feasibility of use of these technologies, availability of methodological support (publications, seminars, teacher training system, Internet support, etc.); availability of an automatic system to track the amount of material learned with user identification and recording the progress of classes; availability of a set of teaching materials (for teacher, for student and for teacher and student); availability of methodological techniques for consolidation of knowledge and skills acquired during classes; availability of interim and/or final forms to control the knowledge of studied material);

- ergonomic design requirements define requirements to: the organization of a dialogue, visual environment, text format and parameters of signs, sound characteristics in accordance with regulatory materials in this area.

In the analysis of convergent methods of ICT use and methods for assessment of their pedagogical and ergonomic quality, it should be noted that they interact meaningfully with health protection approaches to the use of ICT in education, which determine conditions for maintaining the physical and mental health of students who regularly use modern digital technology and, in addition, implement conditions for ensuring personal information security of the subjects of educational process when using ICTs in the process of education.

Therefore, health protection approaches to the use of ICTs by students are connected content-wise with conditions of personal information security of the subjects of the educational process, but in terms of content, we should state that they are interpenetrating.

\section{Conditions for formation of values of domestic education of digital paradigm period in an individual}

The aforementioned elements (or components) are meaningfully based on values of domestic education of the digital paradigm period, as the modern digital transformation of education makes significant adjustments to the meaning of the phrase "values of education" due to a number of significant circumstances. First, it is the contradiction that has arisen in our century between philosophical and psychological values, traditionally humanitarianoriented in the field of education, and financial and economic values, imposed mainly by Western consumerist society, and focused on the acquisition of material values and a variety of services, for multiplication of financial profits. Second, increasing importance of moral and ethical, social and national and cultural values as a counterbalance to the values of consumerist society. Third, it is the need to prevent possible negative effects on the mental and physical health of students who use digital technology for educational purposes. Fourth, it is the need to ensure personal information security of the subjects of the educational process. Fifth, it is the increasing importance of intellectual professions in modern society due to the acceleration of scientific and technological progress and priority of intellectualization of educational activities. Sixth, it is the convergence of pedagogical science and digital technology, manifested in the tendency of agreement, similarity, mutual transfer of characteristic features of pedagogical science and digital technology, as well as the agreement of digital technology methods with teaching methods. [3].

In this case, the values of domestic education of the digital paradigm period will be understood as a characteristic fixated in an individual's mind reflecting his/her attitude to the objects of reality surrounding him/herself. The very content of educational values of the digital paradigm period formed in an individual is a description of ideas, norms, principles significant for an individual and appropriated by him/her when choosing life orientations and priorities set by the student him/herself. [5]. 
Table 1 shows the interrelation of methods and technologies of education, creating a certain integrity (unity), in formation of individual values of education of period of digital paradigm.

Table 1. The interrelation of methods and technologies of education, creating a certain integrity (unity), in formation of individual values of education of period of digital paradigm

\begin{tabular}{|c|c|c|}
\hline $\begin{array}{l}\text { values of } \\
\text { education in } \\
\text { digital } \\
\text { paradigm } \\
\text { period } \\
\text { (content } \\
\text { aspect) }\end{array}$ & $\begin{array}{l}\text { methods for the } \\
\text { formation of values of } \\
\text { education of digital } \\
\text { paradigm period }\end{array}$ & $\begin{array}{l}\text { content of organizational forms, methods and means of } \\
\text { education using technologies of contactless information } \\
\text { interaction; }\end{array}$ \\
\hline $\begin{array}{l}\text { philosophical } \\
\text { and } \\
\text { psychological } \\
\vdots \\
\text { importance } \\
\text { and priority of } \\
\text { adopted in a } \\
\text { particular } \\
\text { society of } \\
\text { humanitarian- } \\
\text { oriented } \\
\text { spiritual, } \\
\text { philosophical, } \\
\text { psychological } \\
\text { general } \\
\text { cultural } \\
\text { aspects of } \\
\text { perception of } \\
\text { reality for an } \\
\text { individual }\end{array}$ & $\begin{array}{l}\text { convergent methods of } \\
\text { training in the use of } \\
\text { ICT in the context of } \\
\text { interpenetration of ICT } \\
\text { methods and methods } \\
\text { of educational } \\
\text { technology; protection } \\
\text { health approaches to the use } \\
\text { of ICT in education; } \\
\text { conditions ensuring } \\
\text { personal information } \\
\text { security of the subjects } \\
\text { of educational process } \\
\text { when using ICTs in the } \\
\text { educational process }\end{array}$ & $\begin{array}{l}\text { Virtual Reality Technology: } \\
\text { - simulation of artificial reality on the screen, simulation of } \\
\text { appearance and properties of real objects or processes, or any } \\
\text { abstractions, necessary from a methodological point of view; } \\
\text { - contactless information interaction of the user with screen } \\
\text { objects and with other users; } \\
\text { - the use of stereo, audio, video, photographic, textual, symbolic, } \\
\text { sensory, and tactile information; } \\
\text { Augmented Reality Technology: } \\
\text { - combining reality and simulated virtual reality, represented by } \\
\text { digital content with simultaneous presentation to the user both } \\
\text { real and virtual objects, processes, stories; } \\
\text { - overlaying digital content on reality represented both by real } \\
\text { objects and in digital (electronic) format. } \\
\text { Mixed Reality Technology (Hybrid Reality): } \\
\text { - combining real and virtual worlds to create digital visualizations } \\
\text { in which objects of reality or real world and virtual reality objects } \\
\text { coexist and interact with each other in real time; } \\
\text { - virtual objects acting according to the laws of real world and the } \\
\text { virtual objects impacting the virtual world; } \\
\text { - mixing virtual reality and reality in the interaction of real and } \\
\text { virtual objects in real time with the ability to transform them. } \\
\text { Technology of contactless information interaction: } \\
\text { - access to external sources of text, graphic, audio, and video } \\
\text { information to search, process, translate, produce, and formalize } \\
\text { it; } \\
\text { - virtual communication between users, their groups represented } \\
\text { on the Internet; } \\
\text { - interaction with an interactive information resource presented } \\
\text { on the Internet; } \\
\text { - combining reality and simulated virtual reality, represented by } \\
\text { digital content with simultaneous presentation to the user both } \\
\text { real and virtual objects, processes, stories; } \\
\text { - overlaying digital content on reality represented both by real } \\
\text { objects and in digital (electronic) format. }\end{array}$ \\
\hline
\end{tabular}


Table 1. Continued

\begin{tabular}{|c|c|c|}
\hline $\begin{array}{l}\text { cognitive and } \\
\text { intellectual: } \\
\text { importance of } \\
\text { cognitive } \\
\text { aspects of } \\
\text { perception of } \\
\text { the } \\
\text { surrounding } \\
\text { reality for an } \\
\text { individual in } \\
\text { the process of } \\
\text { educational, } \\
\text { experimental, } \\
\text { research } \\
\text { activities } \\
\text { related to } \\
\text { learning the } \\
\text { essence of } \\
\text { phenomena, } \\
\text { processes, } \\
\text { objects of a } \\
\text { particular } \\
\text { scientific or } \\
\text { subject area }\end{array}$ & $\begin{array}{l}\text { convergent methods of } \\
\text { training in the use of } \\
\text { ICT in the context of } \\
\text { interpenetration of ICT } \\
\text { methods and methods } \\
\text { of educational } \\
\text { technology; } \\
\text { - methods for } \\
\text { evaluating the } \\
\text { pedagogical and } \\
\text { ergonomic quality of } \\
\text { ICT-based pedagogical } \\
\text { products; protection } \\
\text { health use } \\
\text { approaches to the use } \\
\text { of ICT in education; } \\
\text { conditions ensuring } \\
\text { personal information } \\
\text { security of the subjects } \\
\text { of educational process } \\
\text { when using ICTs in } \\
\text { educational process }\end{array}$ & $\begin{array}{l}\text { Virtual Reality Technology: } \\
\text { - simulation of artificial reality on the screen, simulation of } \\
\text { appearance and properties of real objects or processes, or any } \\
\text { abstractions, necessary from a methodological point of view; } \\
\text { - contactless information interaction of the user with screen } \\
\text { objects and with other users; } \\
\text { - the use of stereo, audio, video, photographic, textual, symbolic, } \\
\text { sensory, and tactile information. } \\
\text { Augmented Reality Technology: } \\
\text { - combining reality and simulated virtual reality, represented by } \\
\text { digital content with simultaneous presentation to the user both } \\
\text { real and virtual objects, processes, stories; } \\
\text { - overlaying digital content on reality represented both by real } \\
\text { objects and in digital (electronic) format } \\
\text { Mixed Reality Technology (Hybrid Reality): } \\
\text { - combining real and virtual worlds to create digital visualizations } \\
\text { in which objects of reality or real world (physical) and virtual } \\
\text { reality objects (digital) coexist and interact with each other in real } \\
\text { time; } \\
\text { - virtual objects acting according to the laws of real world and the } \\
\text { virtual objects impacting the virtual world; } \\
\text { - mixing virtual reality and reality in interaction of real and virtual } \\
\text { objects in real time with the ability to transform them }\end{array}$ \\
\hline $\begin{array}{l}\text { moral and } \\
\text { ethical: } \\
\text { importance } \\
\text { and priority of } \\
\text { adherence to } \\
\text { morals, } \\
\text { honesty, } \\
\text { decency, } \\
\text { ethics, } \\
\text { compassion } \\
\text { and respect in } \\
\text { human } \\
\text { relations } \\
\text { adopted in a } \\
\text { particular } \\
\text { society for an } \\
\text { individual }\end{array}$ & $\begin{array}{l}\text { health protection } \\
\text { approaches to the use } \\
\text { of ICT in education; } \\
\text { conditions ensuring } \\
\text { personal information } \\
\text { security of the subjects } \\
\text { of educational process } \\
\text { when using ICTs in the } \\
\text { educational process }\end{array}$ & $\begin{array}{l}\text { The technology of contactless information interaction: } \\
\text { - access to external sources of text, graphic, audio, and video } \\
\text { information to search, process, translate, produce, and formalize } \\
\text { it; } \\
\text { - virtual communication between users, their groups represented } \\
\text { on the Internet; } \\
\text { - interaction with an interactive information resource presented } \\
\text { on the Internet; } \\
\text { - combining reality and simulated virtual reality, represented by } \\
\text { digital content with simultaneous presentation to the user both } \\
\text { real and virtual objects, processes, stories; } \\
\text { - overlaying digital content on reality represented both by real } \\
\text { objects and in digital (electronic) format }\end{array}$ \\
\hline $\begin{array}{l}\text { national and } \\
\text { ethnic: } \\
\text { priority of } \\
\text { patriotism, } \\
\text { civic duty, } \\
\text { independence } \\
\text { justice, } \\
\text { national } \\
\text { traditions for } \\
\text { an individual } \\
\text { in his/her } \\
\text { decision- } \\
\text { making }\end{array}$ & $\begin{array}{l}\text { health protection } \\
\text { approaches to the use } \\
\text { of ICT in education; } \\
\text { conditions ensuring } \\
\text { personal information } \\
\text { security of the subjects } \\
\text { of educational process } \\
\text { when using ICTs in the } \\
\text { educational process }\end{array}$ & $\begin{array}{l}\text { Technology of contactless information interaction: } \\
\text { - access to external sources of text, graphic, audio, and video } \\
\text { information to search, process, translate, produce, and formalize } \\
\text { it; } \\
\text { - virtual communication between users, their groups represented } \\
\text { on the Internet; } \\
\text { - interaction with an interactive information resource presented } \\
\text { on the Internet; } \\
\text { - combining reality and simulated virtual reality, represented by } \\
\text { digital content with simultaneous presentation to the user both } \\
\text { real and virtual objects, processes, stories; } \\
\text { - overlaying digital content on reality represented both by real } \\
\text { objects and in digital (electronic) format }\end{array}$ \\
\hline
\end{tabular}


Table 1. Continued

\begin{tabular}{|c|c|c|}
\hline $\begin{array}{l}\text { cultural and } \\
\text { aesthetic: } \\
\text { importance of } \\
\text { traditions of } \\
\text { beauty, } \\
\text { harmony, } \\
\text { love, loyalty, } \\
\text { friendship for } \\
\text { an individual } \\
\text { in the } \\
\text { perception of } \\
\text { various } \\
\text { aspects of the } \\
\text { surrounding } \\
\text { reality }\end{array}$ & $\begin{array}{l}\text { conditions ensuring } \\
\text { personal information } \\
\text { security of the subjects } \\
\text { of educational process } \\
\text { when using ICTs in } \\
\text { educational process }\end{array}$ & $\begin{array}{l}\text { Technology of contactless information interaction: } \\
\text { - access to external sources of text, graphic, audio, and video } \\
\text { information to search, process, translate, produce, and formalize } \\
\text { it; } \\
\text { - virtual communication between users, their groups represented } \\
\text { on the Internet; } \\
\text { - interaction with an interactive information resource presented } \\
\text { on the Internet; } \\
\text { - combining reality and simulated virtual reality, represented by } \\
\text { digital content with simultaneous presentation to the user both } \\
\text { real and virtual objects, processes, stories; } \\
\text { - overlaying digital content on reality represented both by real } \\
\text { objects and in digital (electronic) format }\end{array}$ \\
\hline $\begin{array}{l}\text { Convergent: } \\
\text { importance } \\
\text { (for an } \\
\text { individual) of } \\
\text { education } \\
\text { through } \\
\text { pedagogical } \\
\text { and } \\
\text { technological } \\
\text { and teaching } \\
\text { materials that } \\
\text { ensure the } \\
\text { agreement of } \\
\text { teaching } \\
\text { methods with } \\
\text { the methods } \\
\text { of ICT or } \\
\text { implement a } \\
\text { mutual } \\
\text { transfer of } \\
\text { characteristic } \\
\text { s ef } \\
\text { educational } \\
\text { technology } \\
\text { and ICTs }\end{array}$ & $\begin{array}{l}\text { convergent methods of } \\
\text { training in the use of } \\
\text { ICT in the context of } \\
\text { interpenetration of ICT } \\
\text { methods and methods } \\
\text { of educational } \\
\text { technology; } \\
\text { - methods for } \\
\text { evaluating pe the } \\
\text { pedagogical and } \\
\text { ergonomic quality of } \\
\text { ICT-based pedagogical } \\
\text { products; } \\
\text { conditions ensuring } \\
\text { personal information } \\
\text { security of the subjects } \\
\text { of educational process } \\
\text { when using ICTs }\end{array}$ & $\begin{array}{l}\text { Augmented Reality Technology: } \\
\text { - combining reality and simulated virtual reality, represented by } \\
\text { digital content with simultaneous presentation to the user both } \\
\text { real and virtual objects, processes, stories; } \\
\text { - overlaying digital content on reality represented both by real } \\
\text { objects and in digital (electronic) format. } \\
\text { Mixed Reality Technology (Hybrid Reality): } \\
\text { - combining real and virtual worlds to create digital visualizations } \\
\text { in which objects of reality or real world (physical) and virtual } \\
\text { reality objects (digital) coexist and interact with each other in real } \\
\text { time; } \\
\text { - virtual objects acting according to the laws of real world and the } \\
\text { virtual objects impacting the virtual world; } \\
\text { - mixing virtual reality and reality in interaction of real and virtual } \\
\text { objects in real time with the ability to transform them }\end{array}$ \\
\hline $\begin{array}{l}\text { health } \\
\text { protection: } \\
\text { obligation for } \\
\text { an individual } \\
\text { to comply } \\
\text { with } \\
\text { psychological } \\
\text {, pedagogical, } \\
\text { sanitary, } \\
\text { hygienic and } \\
\text { technical } \\
\text { requirements } \\
\text { while } \\
\text { carrying out } \\
\text { educational } \\
\text { activities }\end{array}$ & $\begin{array}{l}\text { health protection } \\
\text { approaches to the use } \\
\text { of ICT in education; } \\
\text { - methods for } \\
\text { evaluating pand the } \\
\text { pedagogical and } \\
\text { ergonomic quality of } \\
\text { ICT-based pedagogical } \\
\text { products; }\end{array}$ & $\begin{array}{l}\text { The technology of contactless information interaction: } \\
\text { - access to external sources of text, graphic, audio, and video } \\
\text { information to search, process, translate, produce, and formalize } \\
\text { it; } \\
\text { - virtual communication between users, their groups represented } \\
\text { on the Internet; } \\
\text { - interaction with an interactive information resource presented } \\
\text { on the Internet; } \\
\text { - combining reality and simulated virtual reality, represented by } \\
\text { digital content with simultaneous presentation to the user both } \\
\text { real and virtual objects, processes, stories; } \\
\text { - overlaying digital content on reality represented both by real } \\
\text { objects and in digital (electronic) format. } \\
\text { Virtual Reality Technology: } \\
\text { - simulation of artificial reality on the screen, simulation of } \\
\text { appearance and properties of real objects or processes, or any } \\
\text { abstractions, necessary from a methodological point of view; } \\
\text { - contactless information interaction of the user with screen } \\
\text { objects (sensory, tactile realization) and with other users; } \\
\text { - the use of stereo, audio, video, photographic, textual, symbolic, } \\
\text { sensory, and tactile information }\end{array}$ \\
\hline
\end{tabular}


Table 1. Continued

\begin{tabular}{|c|c|c|}
\hline $\begin{array}{l}\text { personal } \\
\text { information } \\
\text { security } \\
\text { involves } \\
\text { obligation of } \\
\text { an individual } \\
\text { to block the } \\
\text { information } \\
\text { that is: } \\
\text { - forbidden by } \\
\text { law, } \\
\text { - affront to } \\
\text { moral values, } \\
\text { - aggressive, } \\
\text { - illegal, } \\
\text { - humiliating } \\
\text { or insulting to } \\
\text { human } \\
\text { dignity }\end{array}$ & $\begin{array}{l}\text { conditions ensuring } \\
\text { personal information } \\
\text { security of the subjects } \\
\text { of educational process } \\
\text { when using ICTs in the } \\
\text { educational process } \\
\text { health protection } \\
\text { approaches to the use } \\
\text { of ICT in education }\end{array}$ & $\begin{array}{l}\text { Virtual Reality Technology: } \\
\text { - simulation of artificial reality on the screen, simulation of } \\
\text { appearance and properties of real objects or processes, or any } \\
\text { abstractions, necessary from a methodological point of view; } \\
\text { - contactless information interaction of the user with screen } \\
\text { objects (sensory, tactile realization) and with other users; } \\
\text { - the use of stereo, audio, video, photographic, textual, symbolic, } \\
\text { sensory, and tactile information. } \\
\text { The technology of contactless information interaction: } \\
\text { - access to external sources of text, graphic, audio, and video } \\
\text { information to search, process, translate, produce, and formalize } \\
\text { it; } \\
\text { - virtual communication between users, their groups represented } \\
\text { on the Internet; } \\
\text { - interaction with an interactive information resource presented } \\
\text { on the Internet; } \\
\text { - combining reality and simulated virtual reality, represented by } \\
\text { digital content with simultaneous presentation to the user both } \\
\text { real and virtual objects, processes, stories; } \\
\text { - overlaying digital content on reality represented both by real } \\
\text { objects and in digital (electronic) format }\end{array}$ \\
\hline
\end{tabular}

The interrelation of methods (middle column of the table) and technologies (right column of the table) presented in the table, forming certain integrity (unity) in the formation of an individual's values of education of digital paradigm period (left column of the table) reveals the content basis:

- methods of formation of educational values and technologies, the implementation of which contributes to the formation of educational values of digital paradigm period;

- values of modern education, formed in an individual with the help of appropriate methods and technologies.

These positions can be reflected in competencies, in knowledge and skills required for a modern student who systematically uses digital technology for educational purposes.

Thus, consideration of the essence of components of scientific views on theoretical, methodological developments and technological solutions, focused on the formation of a digital education paradigm, allows us to state the following:

- components (in our case: convergent teaching methods, values of education of digital transformation period; methods for evaluating the pedagogical and ergonomic quality of ICT-based pedagogical products; health protection approaches to ICT use in education; conditions for personal information security of the subjects of educational process when using ICT in the process of education) are considered as a set of interrelated components;

- a finite set of elements (components) which are connected and interrelated with each other, form certain integrity, unity as a system of scientific views on methodological, scientific-pedagogical provisions and technological solutions (or theoretical, methodological developments and technological solutions) for formation of a digital education paradigm.

\section{Formation of a digital paradigm of national education based on systemic convergence of pedagogical science and technology}

To form a digital paradigm of domestic education as a system of scientific views on theoretical, methodological, and technological solutions for the formation of a digital education paradigm, we shall refer to the concept of convergence of pedagogical science and ICT [3], by which we mean:

- merging or fusion (partial or fragmentary) of different scientific or methodological areas; 
- mutual transfer of characteristic properties of educational technology and ICTs;

- agreement of ICT methods with organizational forms and methods inherent in pedagogical science, their mutual influence on each other, their evolutionary approximation;

- diffusion of ICT methods into teaching methods and, as a consequence, their approximation or agreement.

Table 2 shows the transfer of content of some results of basic and applied scientific research in the area of education informatization into the content of practice-oriented components.

Table 2. The transfer of content of some results of basic and applied scientific research in the area of education informatization into the content of practice-oriented components.

\begin{tabular}{|c|c|c|}
\hline $\begin{array}{l}\text { results of basic and applied } \\
\text { scientific research (BASR) in the } \\
\text { field of informatization of } \\
\text { education: }\end{array}$ & $\begin{array}{l}\text { components of digital } \\
\text { education paradigm: }\end{array}$ & $\begin{array}{l}\text { mutual transfer of content of } \\
\text { BASR results and } \\
\text { components of digital } \\
\text { education paradigm into: }\end{array}$ \\
\hline 1 & 2 & 3 \\
\hline $\begin{array}{l}\text { - organizational forms, methods } \\
\text { and means of education, } \\
\text { corresponding to the achievements } \\
\text { of scientific and technological } \\
\text { progress of modern society, under } \\
\text { condition of personal information } \\
\text { security and protection of health of } \\
\text { the subjects of the educational } \\
\text { process; } \\
\text { - organizational and } \\
\text { methodological conditions for } \\
\text { prevention of possible negative } \\
\text { consequences of psychological, } \\
\text { pedagogical, social, cultural and } \\
\text { medical nature when using ICTs } \\
\text { for educational purposes; }\end{array}$ & $\begin{array}{l}\text { - convergent methods of } \\
\text { using ICT in the process } \\
\text { of education; } \\
-\quad \text { methods ensuring } \\
\text { personal information } \\
\text { security of the subjects } \\
\text { of educational process } \\
\text { when using ICTs; } \\
\text { - health protection } \\
\text { approaches to the use of } \\
\text { ICT in education; }\end{array}$ & $\begin{array}{l}\text { - content of organizational } \\
\text { forms, methods and means of } \\
\text { education using technologies } \\
\text { that display the reality in virtual } \\
\text { reality with contactless } \\
\text { information impact on its } \\
\text { objects and processes; } \\
\text { - content of measures on health } \\
\text { protection of students as users } \\
\text { of ICT; } \\
\text { - content of measures on } \\
\text { personal information security of } \\
\text { the subjects of the educational } \\
\text { process; }\end{array}$ \\
\hline $\begin{array}{l}\text { pedagogical and ergonomic } \\
\text { requirements for the creation and } \\
\text { use of pedagogical products, } \\
\text { functioning on the basis of ICT, in } \\
\text { conditions of personal information } \\
\text { security and health protection of } \\
\text { the subjects of the educational } \\
\text { process; }\end{array}$ & 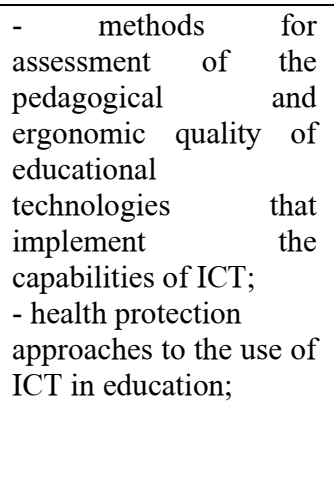 & $\begin{array}{l}\text { - content of psychological and } \\
\text { pedagogical, content-related } \\
\text { and methodological, design and } \\
\text { ergonomic requirements for } \\
\text { pedagogical products } \\
\text { functioning on the basis of ICT; } \\
\text { - content of measures on health } \\
\text { protection of students as users } \\
\text { of ICT; } \\
\text { - content of measures on } \\
\text { personal information security of } \\
\text { the subjects of the educational } \\
\text { process; }\end{array}$ \\
\hline
\end{tabular}


Table 2. Continued

\begin{tabular}{|c|c|c|}
\hline $\begin{array}{l}\text { - conditions of designing } \\
\text { educational technologies, relevant } \\
\text { from the pedagogical point of } \\
\text { view, based on the implementation } \\
\text { of possibilities: contactless } \\
\text { information interaction } \\
\text { technologies, as well as didactic } \\
\text { and methodological support of } \\
\text { their use in the educational process }\end{array}$ & $\begin{array}{l}\text { - methods of using ICT } \\
\text { in the process of } \\
\text { education; } \\
\text { - methods for } \\
\text { assessment of the } \\
\text { pedagogical and } \\
\text { ergonomic quality of } \\
\text { educational } \\
\text { technologies } \\
\text { implement that } \\
\text { capabilities of ICT }\end{array}$ & $\begin{array}{l}\text { - content of organizational } \\
\text { forms, methods and means of } \\
\text { education using technologies of } \\
\text { contactless information } \\
\text { interaction; } \\
\text { - content of psychological and } \\
\text { pedagogical, content-related } \\
\text { and methodological, design and } \\
\text { ergonomic requirements for } \\
\text { pedagogical products } \\
\text { functioning on the basis of ICT; }\end{array}$ \\
\hline $\begin{array}{l}\text { - establishment and development } \\
\text { of digital transformation of } \\
\text { education based on the systemic } \\
\text { convergence of pedagogical } \\
\text { science and ICT as a result of } \\
\text { significant changes in education, in } \\
\text { connection with the } \\
\text { implementation of achievements of } \\
\text { modern scientific and } \\
\text { technological progress; } \\
\text { implementation and improvement } \\
\text { of new learning theories (theory of } \\
\text { convergence of pedagogical } \\
\text { science and ICT; theory of health } \\
\text { protection when using ICT; theory } \\
\text { of personal information security of } \\
\text { the subjects of the educational } \\
\text { process, theory of immersive } \\
\text { educational technology design); }\end{array}$ & $\begin{array}{l}\text { - methods of using ICT } \\
\text { in the process of } \\
\text { education; } \\
\text { - provision of personal } \\
\text { information security of } \\
\text { the subjects of } \\
\text { educational process } \\
\text { when using ICTs in } \\
\text { education; } \\
\text { - health protection } \\
\text { approaches to the use of } \\
\text { ICT in education; }\end{array}$ & $\begin{array}{l}\text { - content of convergent methods } \\
\text { of using ICT in the process of } \\
\text { education; } \\
\text { - content of organizational } \\
\text { forms, methods and means of } \\
\text { education using technologies } \\
\text { that display the reality in virtual } \\
\text { reality with contactless } \\
\text { information impact on its } \\
\text { objects and processes; } \\
\text { - content of measures on health } \\
\text { protection of students as users } \\
\text { of ICT; } \\
\text { - content of measures on } \\
\text { personal information security of } \\
\text { the subjects of the educational } \\
\text { process; }\end{array}$ \\
\hline
\end{tabular}

\section{Conclusion}

In conclusion, we should note that the development of digital transformation of domestic education based on systemic convergence of pedagogical science and technology in connection to the process of development of organizational forms and methods of using ICTs involves:

- referring to the results of basic and applied scientific research, representing theoretical, methodological developments and technological solutions, corresponding to the period of digital transformation of education;

- identifying conditions for the transfer of the content of some of the results of basic and applied scientific research in the area of education informatization in the content of practiceoriented components;

- revealing interrelation of teaching methods and technologies and their implementation in the formation of the value of education of digital paradigm period in an individual;

- implementing intellectualization of educational and cognitive activity; expanding students' understanding of the content of learning material through virtual models of studied objects and processes; implementing informational activities and informational interaction;

- preventing possible negative effects of ICT use on the student;

- providing personal information security of the subjects of the educational process as users of ICT. 


\section{References}

1. I.Sh. Mukhametzyanov, Informatization of education and science, 1(29), 3 (2016)

2. V.P. Polyakov, Yu.A. Romanenko, Human Science: Humanities Research, 39 (2020)

3. I.V. Robert, Convergence of educational sciences and information technologies as an evolutionary approximation of sciences and technologies (for researchers and teachers of professional education institutions), 54 (2014)

4. I.V. Robert, Informatization of education and science, 3(43), 119 (2019)

5. I.V. Robert, Educational informatics, 2, 89 (2020)

6. I.V. Robert, Educational informatics, 3, 141 (2020)

7. I.V. Robert, Informatization of education and science, 3(47), 3 (2020)

8. I.V. Robert, International online seminar: Distance education in the Republic of Korea and the Russian Federation in the post-coronavirus era: the main provisions and directions, Korea, 259 (2020)

9. I.V. Robert, E-learning and distance education technologies, Theory and practice, 1, 136 (2017)

10. I. Mukhametzyanov, O. Kozlov, V. Polyakov, InnoCSE 2019, Innovative Approaches in Computer Science within Higher Education, Ekaterinburg, Russia, 223 (2019)

11. I.V. Robert, Proceedings of the International Conference on the Development of Education in Russia and the CIS Member States (ICEDER 2018), Moscow, 36 (2018)

12. I.V. Robert, SHS Web of Conferences, France 47, 01056-62(2018)

13. Dr Charlotte Coles, Augmented and Virtual Reality: Technology of the Future, Today (2020) https://www.idtechex.com/

14. Accenture, Accenture Extended Reality (XR) Services, https://www.accenture.com/

15. Holographica, https://holographica.space/

16. GitHub, https://microsoft.github.io/

17. Jasoren, https://jasoren.com/

18. Use Cases of Augmented Reality in Education and Training, https://rubygarage.org/

19. Augmented Reality: The Future of Education, https://interestingengineering.com/

20. ResearchGate, https://www.researchgate.net/

21. TeachThought, https://www.teachthought.com/

22. Augmented reality in the classroom: ideas for digitizing education and training, https://overlyapp.com/

23. How VR In Education Will Change How We Learn And Teach, https://xd.adobe.com/

24. Engaging VR and AR educational content for students of all ages, https://www.classvr.com/

25. Virtual Reality in Education: Benefits, Tools, and Resources, https://soeonline.american.edu/

26. Immersion VR, https://immersionvr.co.uk/

27. Virtual Reality In Education - How Are Schools Using VR, https://www.viar360.com/

28. Virtual Reality for Education Theme by HB-Themes, http://virtualrealityforeducation.com/

29. Criss, https://www.crissh2020.eu/

30. Built In 2019, https://builtin.com/ 
31. The Science of Person: Humanitarian Researches, http://journal.omga.su/ 